Annals of Pure and Applied Mathematics

Vol. 15, No. 2, 2017, 235-242

ISSN: 2279-087X (P), 2279-0888(online)

Published on 11 December 2017

www.researchmathsci.org

DOI: http://dx.doi.org/10.22457/apam.v15n2a10

Annals of

Pure and Applied

Mathematics

\title{
On Antipodal Single Valued Neutrosophic Graph
}

\author{
J. Malarvizhi ${ }^{1}$ and G.Divya ${ }^{2}$ \\ PG and Research Department of Mathematics \\ K.N.Govt. Arts College (Autonomous) for Women \\ Thanjavur - 7, Tamilnadu, India. \\ ${ }^{1}$ Email: mathmalar270763@gmail.com; ${ }^{2}$ Email: mathsdivya3@gmail.com \\ Received 10 October 2017; accepted 9 December 2017
}

Abstract. In this paper we define Antipodal single valued neutrosophic graph and some Isomorphic properties of Antipodal single valued neutrosophic graph are discussed.

Keywords: Single valued neutosophic graph, antipodal single valued neutrosophic graph

AMS Mathematics Subject Classification (2010): $05 \mathrm{C} 72$

\section{Introduction}

Graph theory has been highly successful in certain academic fields, including natural sciences and engineering. Graph theoretic models can sometimes provide a useful structure upon which analytical techniques can be used. It is often convenient to depict the relationships between pairs of elements of a system by means of a graph or a digraph. The vertices of the graph represent the system elements and its edges or arcs represent the relationships between the elements. This approach is especially useful for transportation, scheduling, sequencing, allocation, assignment, and other problems which can be modelled as networks. Such a graph theoretic model is often useful as an aid in communicating. Zadeh introduced the concept of fuzzy set. Attanassov introduced the intuitionistic fuzzy sets which is a generalization of fuzzy sets. Fuzzy set theory and intuitionistic fuzzy sets theory are useful models for dealing with uncertainty and incomplete information. But they may not be sufficient in modeling of indeterminate and inconsistent information encountered in real world. In order to cope with this issue, neutrosophic set theory was proposed by Smarandache as a generalization of fuzzy sets and intuitionistic fuzzy sets. Neutrosophic set proposed by Smarandache is a powerful tool to deal with incomplete, indeterminate and inconsistent information in real world. It is a generalization of the theory of fuzzy set, intuitionistic fuzzy sets, interval-valued fuzzy sets and interval-valued intuitionistic fuzzy sets, then the neutrosophic set is characterized by a truth-membership degree (T), an indeterminacy-membership degree (I) and a falsity-membership degree $(\mathrm{F})$ independently, which are within the real standard or nonstandard unit interval $]^{-} 0,1^{+}[$. There are some difficulties in modeling of some problems in Engineering and Sciences. To overcome these difficulties, in 2010, concept of single-valued neutrosophic sets and its operations were defined by Wang et al. as a generalization of intuitionistic fuzzy sets. 


\section{J. Malarvizhi and G.Divya}

In crisp graph theory the concept of antipodal graph of a given graph $\mathrm{G}$ was introduced by Smith. In fuzzy graph theory the concept of antipodal fuzzy graph of a given fuzzy graph was introduced [1].

In this paper we define Antipodal single valued neutrosophic graph and some Isomorphic properties of Antipodal single valued neutrosophic graph are discussed.

\section{Preliminaries}

Definition 2.1. [5] Let G: $(\sigma, \mu)$ be a fuzzy graph with the underlying set V.

$A(G):(\sigma A(G), \mu A(G))$ is defined as follows:

The node set of $G$ is taken as the node set of $A(G)$ also. Two nodes in $A(G)$ are made as neighbors if the $\mu$ - distance between them is diam $(\mathrm{G})$.i.e.,

$\sigma_{\mathrm{A}(\mathrm{G})}(\mathrm{u})=\sigma(\mathrm{u})$ for all $\mathrm{u} \in \mathrm{V}$ and if $\delta(\mathrm{u}, \mathrm{v})=\operatorname{diam}(\mathrm{G})$ then

$\mu_{\mathrm{A}(\mathrm{G})}(\mathrm{u}, \mathrm{v})=\mu(\mathrm{u}, \mathrm{v})$ if $\mathrm{u}$ and $\mathrm{v}$ are neighbors in $\mathrm{G}$

$=\sigma(\mathrm{u}) \wedge \sigma(\mathrm{v})$ if $\mathrm{u}$ and $\mathrm{v}$ are not neighbors in $\mathrm{G}$

$\mu_{\mathrm{A}(\mathrm{G})}(\mathrm{u}, \mathrm{v})=0$ otherwise.

This pair $\mathrm{A}(\mathrm{G})$ is a fuzzy graph, because $\sigma_{\mathrm{A}(\mathrm{G})}(\mathrm{u})=\sigma(\mathrm{u})$ for all $\mathrm{u} \in \mathrm{V}$ implies $\sigma_{\mathrm{A}(\mathrm{G})}$ is a fuzzy subset on $\mathrm{V}$ and by the definition of $\mu_{\mathrm{A}(\mathrm{G})}$, it is a fuzzy relation on $\sigma_{\mathrm{A}(\mathrm{G})}$, such that, $\mu_{\mathrm{A}(\mathrm{G})}(\mathrm{u}, \mathrm{v}) \leq \sigma(\mathrm{u}) \wedge \sigma(\mathrm{v})=\sigma_{\mathrm{A}(\mathrm{G})}(\mathrm{u}) \wedge \sigma_{\mathrm{A}(\mathrm{G})}(\mathrm{v})$ for all $\mathrm{u}, \mathrm{v}$ in $\mathrm{V}$. This fuzzy graph $\mathrm{A}(\mathrm{G})$ is termed as Antipodal fuzzy graph of $\mathrm{G}$.

Definition 2.2. [8] Let $X$ be a space of points (objects). A neutrosophic set A in $X$ is characterized by a truth-membership function $\mathrm{T}_{\mathrm{A}}(\mathrm{x})$, an indeterminacy-membership function $\mathrm{I}_{A}(\mathrm{x})$ and a falsity-membership function $\mathrm{F}_{\mathrm{A}}(\mathrm{x})$. The functions $\mathrm{T}_{\mathrm{A}}(\mathrm{x}), \mathrm{I}_{\mathrm{A}}(\mathrm{x})$, and $\mathrm{F}_{\mathrm{A}}(\mathrm{x})$ are real standard or non-standard subsets of $] 0^{-}, 1^{+}\left[\right.$. That is, $\left.\mathrm{T}_{\mathrm{A}}(\mathrm{x}): \mathrm{X} \rightarrow\right] 0^{-}, 1^{+}[$, $\left.\mathrm{I}_{\mathrm{A}}(\mathrm{x}): \mathrm{X} \rightarrow\right] 0^{-}, 1^{+}\left[\right.$and $\left.\mathrm{F}_{\mathrm{A}}(\mathrm{x}): \mathrm{X} \rightarrow\right] 0^{-}, 1^{+}\left[\right.$and $0^{-} \leq \mathrm{T}_{\mathrm{A}}(\mathrm{x})+\mathrm{I}_{\mathrm{A}}(\mathrm{x})+\mathrm{F}_{\mathrm{A}}(\mathrm{x}) \leq 3^{+}$.

Definition 2.3. [7] A Single-Valued Neutrosophic graph $(S V N$ graph $)$ is a pair $G=(A, B)$ of the crisp graph $G^{*}=(V, E)(i . e .$, with underlying set $V$ ), where $A: V \rightarrow[0,1]$ is single-valued neutrosophic set in $\mathrm{V}$ and $\mathrm{B}: \mathrm{V} \times \mathrm{V} \rightarrow[0,1]$ is single-valued neutrosophic relation on $\mathrm{V}$ such that

$$
\begin{aligned}
& \mathrm{T}_{\mathrm{B}}(\mathrm{xy}) \leq \min \left\{\mathrm{T}_{\mathrm{A}}(\mathrm{x}), \mathrm{T}_{\mathrm{A}}(\mathrm{y})\right\}, \\
& \mathrm{I}_{\mathrm{B}}(\mathrm{xy}) \leq \min \left\{\mathrm{I}_{\mathrm{A}}(\mathrm{x}), \mathrm{I}_{\mathrm{A}}(\mathrm{y})\right\}, \\
& \mathrm{F}_{\mathrm{B}}(\mathrm{xy}) \leq \max \left\{\mathrm{F}_{\mathrm{A}}(\mathrm{x}), \mathrm{F}_{\mathrm{A}}(\mathrm{y})\right\}
\end{aligned}
$$

for all $\mathrm{x}, \mathrm{y} \in \mathrm{V}$. A is called single-valued neutrosophic vertex set of $\mathrm{G}$ and $\mathrm{B}$ is called single-valued neutrosophic edge set of G, respectively.

\section{Example 1.}

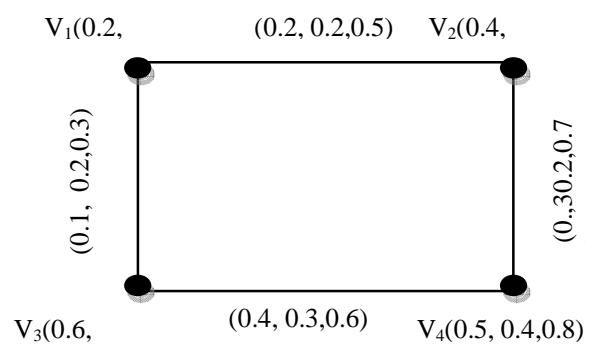

Figure 1: Single valued neutrosophic graph 


\section{On Antipodal Single Valued Neutrosophic Graph}

Definition 2.4. A partial single valued neutrosophic subgraph of a single valued neutrosophic graph $G=(A, B)$ is a single valued neutrosophic graph $H=\left(A^{\prime}, B^{\prime}\right)$ such that

i) $\mathrm{A}^{\prime} \subseteq \mathrm{A}$ where $\mathrm{T}_{\mathrm{A}^{\prime}}\left(\mathrm{v}_{\mathrm{i}}\right) \leq \mathrm{T}_{\mathrm{A}}\left(\mathrm{v}_{\mathrm{i}}\right), \mathrm{I}_{\mathrm{A}^{\prime}}\left(\mathrm{v}_{\mathrm{i}}\right) \leq \mathrm{I}\left(\mathrm{v}_{\mathrm{i}}\right), \mathrm{F}_{\mathrm{A}^{\prime}}\left(\mathrm{v}_{\mathrm{i}}\right) \leq \mathrm{F}_{\mathrm{A}}\left(\mathrm{v}_{\mathrm{i}}\right)$ for all $\mathrm{v}_{\mathrm{i}} \in \mathrm{A}^{\prime}$

ii) $\mathrm{B}^{\prime} \subseteq \mathrm{B}$ where $\mathrm{T}_{\mathrm{B}^{\prime}}\left(\mathrm{v}_{\mathrm{i}}, \mathrm{v}_{\mathrm{j}}\right) \leq \mathrm{T}_{\mathrm{B}}\left(\mathrm{v}_{\mathrm{i}}, \mathrm{v}_{\mathrm{j}}\right), \mathrm{I}_{\mathrm{B}^{\prime}}\left(\mathrm{v}_{\mathrm{i}}, \mathrm{v}_{\mathrm{j}}\right) \leq \mathrm{I}_{\mathrm{B}}\left(\mathrm{v}_{\mathrm{i}}, \mathrm{v}_{\mathrm{j}}\right), \mathrm{F}_{\mathrm{B}^{\prime}}\left(\mathrm{v}_{\mathrm{i}}, \mathrm{v}_{\mathrm{j}}\right) \leq \mathrm{F}_{\mathrm{B}}\left(\mathrm{v}_{\mathrm{i}}, \mathrm{v}_{\mathrm{j}}\right)$ for every $\left(v_{i}, v_{j}\right) \in B^{\prime}$.

Definition 2.5. A single valued neutrosophic subgraph of a single valued neutrosophic graph $G=(A, B)$ is a single valued neutrosophic graph $H=\left(A^{\prime}, B^{\prime}\right)$ such that

i) $\mathrm{A}^{\prime} \subseteq \mathrm{A}$ where $\mathrm{T}_{\mathrm{A}^{\prime}}\left(\mathrm{v}_{\mathrm{i}}\right)=\mathrm{T}_{\mathrm{A}}\left(\mathrm{v}_{\mathrm{i}}\right), \mathrm{I}_{\mathrm{A}^{\prime}}\left(\mathrm{v}_{\mathrm{i}}\right)=\mathrm{I}\left(\mathrm{v}_{\mathrm{i}}\right), \mathrm{F}_{\mathrm{A}^{\prime}}\left(\mathrm{v}_{\mathrm{i}}\right)=\mathrm{F}_{\mathrm{A}}\left(\mathrm{v}_{\mathrm{i}}\right)$ for all $\mathrm{v}_{\mathrm{i}} \in \mathrm{A}^{\prime}$

ii) $\mathrm{B}^{\prime} \subseteq \mathrm{B}$ where $\mathrm{T}_{\mathrm{B}^{\prime}}\left(\mathrm{v}_{\mathrm{i}}, \mathrm{v}_{\mathrm{j}}\right)=\mathrm{T}_{\mathrm{B}}\left(\mathrm{v}_{\mathrm{i}}, \mathrm{v}_{\mathrm{j}}\right), \mathrm{I}_{\mathrm{B}^{\prime}}\left(\mathrm{v}_{\mathrm{i}}, \mathrm{v}_{\mathrm{j}}\right)=\mathrm{I}_{\mathrm{B}}\left(\mathrm{v}_{\mathrm{i}}, \mathrm{v}_{\mathrm{j}}\right), \mathrm{F}_{\mathrm{B}^{\prime}}\left(\mathrm{v}_{\mathrm{i}}, \mathrm{v}_{\mathrm{j}}\right)=\mathrm{F}_{\mathrm{B}}\left(\mathrm{v}_{\mathrm{i}}, \mathrm{v}_{\mathrm{j}}\right)$ for every $\left(v_{i}, v_{j}\right) \in B^{\prime}$.

Definition 2.6. The two vertices are said to be adjacent in a single valued neutrosophic graph $\mathrm{G}=(\mathbf{A}, \mathbf{B})$ if $\mathrm{T}_{\mathrm{B}}(\mathrm{x}, \mathrm{y})=\min \left\{\mathrm{T}_{\mathrm{A}}(\mathrm{x}), \mathrm{T}_{\mathrm{A}}(\mathrm{y})\right\}$,

$$
\begin{aligned}
\mathrm{I}_{\mathrm{B}}(\mathrm{x}, \mathrm{y}) & =\min \left\{\mathrm{I}_{\mathrm{A}}(\mathrm{x}), \mathrm{I}_{\mathrm{A}}(\mathrm{y})\right\}, \\
\mathrm{F}_{\mathrm{B}}(\mathrm{x}, \mathrm{y}) & =\max \left\{\mathrm{F}_{\mathrm{A}}(\mathrm{x}), \mathrm{F}_{\mathrm{A}}(\mathrm{y})\right\} .
\end{aligned}
$$

In this case, $\mathrm{x}$ and $\mathrm{y}$ are said to be neighbors and $(\mathrm{x}, \mathrm{y})$ is incident on $\mathrm{x}$ and $\mathrm{y}$.

Definition 2.7. [7] A single-valued neutrosophic graph $G=(A, B)$ is called completeif the following conditions are satisfied:

$$
\begin{aligned}
& \mathrm{T}_{\mathrm{B}}(\mathrm{x}, \mathrm{y})=\min \left\{\mathrm{T}_{\mathrm{A}}(\mathrm{x}), \mathrm{T}_{\mathrm{A}}(\mathrm{y})\right\}, \\
& \mathrm{I}_{\mathrm{B}}(\mathrm{x}, \mathrm{y})=\min \left\{\mathrm{I}_{\mathrm{A}}(\mathrm{x}), \mathrm{I}_{\mathrm{A}}(\mathrm{y})\right\}, \\
& \mathrm{F}_{\mathrm{B}}(\mathrm{x}, \mathrm{y})=\max \left\{\mathrm{F}_{\mathrm{A}}(\mathrm{x}), \mathrm{F}_{\mathrm{A}}(\mathrm{y})\right\}
\end{aligned}
$$

for all $\mathrm{x}, \mathrm{y} \in \mathrm{V}$.

Definition 2.8. [4] A single valued neutrosophic path $P$ in a single valued neutrosophic graph $\mathrm{G}=(\mathbf{A}, \mathbf{B})$ is a sequence of distinct vertices $\mathrm{v}_{0}, \mathrm{v}_{1}, \mathrm{v}_{2}, \ldots \mathrm{v}_{\mathrm{n}}$ such that $\mathrm{T}_{\mathrm{B}}\left(\mathrm{v}_{\mathrm{i}-1}, \mathrm{v}_{\mathrm{i}}\right)>$ $0, I_{B}\left(v_{i-1}, v_{i}\right)>0$ and $F_{B}\left(v_{i-1}, v_{i}\right)>0$ for $0 \leq i \leq 1$. Here $n \geq 1$ is called the length of the path $\mathrm{P}$. The consecutive pairs $\left(\mathrm{v}_{\mathrm{i}-1}, \mathrm{v}_{\mathrm{i}}\right)$ are called edges of the path.

A single node or vertex $v_{i}$ may also be considered as a path. In this case the path is of the length 0 .

We call $P$ a cycle if $v_{0}=v_{n}$ andn $\geq 3$.

Definition 2.9. [4] A single valued neutrosophic graph $G=(A, B)$ is said to be connected if every pair of vertices has at least one single valued neutrosophic path between them, otherwise it is disconnected.

Definition 2.10. Let $\mathrm{G}$ be a connected single valued neutrosophic graph.

The $\mathrm{T}-\operatorname{distance} \delta(\mathrm{u}, \mathrm{v})$, is the smallest $\mathrm{T}-$ length of any $\mathrm{u}-\mathrm{v}$ path

$\mathrm{P}: \mathrm{u}=\mathrm{v}_{0}, \mathrm{v}_{1}, \mathrm{v}_{2}, \ldots \mathrm{v}_{\mathrm{n}}=\mathrm{v}$ in $\mathrm{G}$ is $\ell_{\mathrm{T}}(\mathrm{P})=\sum_{\mathrm{i}=1}^{\mathrm{n}} \frac{1}{\mathrm{~T}_{\mathrm{B}}\left(\mathrm{v}_{\mathrm{i}-1}, \mathrm{v}_{\mathrm{i}}\right)}$, where $\mathrm{v}_{\mathrm{i}} \in \mathrm{V}$,

i.e., $\delta_{\mathrm{T}}(\mathrm{u}, \mathrm{v})=\min \left(\ell_{\mathrm{T}}(\mathrm{P})\right)$.

The I - distance $\delta(\mathrm{u}, \mathrm{v})$, is the smallest I - length of any $\mathrm{u}-\mathrm{v}$ path

$\mathrm{P}: \mathrm{u}=\mathrm{v}_{0}, \mathrm{v}_{1}, \mathrm{v}_{2}, \ldots \mathrm{v}_{\mathrm{n}}=\mathrm{v}$ in $\mathrm{G}$ is $\ell_{\mathrm{I}}(\mathrm{P})=\sum_{\mathrm{i}=1}^{\mathrm{n}} \frac{1}{\mathrm{I}_{\mathrm{B}}\left(\mathrm{v}_{\mathrm{i}-1}, \mathrm{v}_{\mathrm{i}}\right)}$, where $\mathrm{v}_{\mathrm{i}} \in \mathrm{V}$, 


\section{J. Malarvizhi and G.Divya}

i.e., $\delta_{\mathrm{I}}(\mathrm{u}, \mathrm{v})=\min \left(\ell_{\mathrm{I}}(\mathrm{P})\right)$.

The $\mathrm{F}-\operatorname{distance} \delta(\mathrm{u}, \mathrm{v})$, is the smallest $\mathrm{F}-$ length of any $\mathrm{u}-\mathrm{v}$ path

$\mathrm{P}: \mathrm{u}=\mathrm{v}_{0}, \mathrm{v}_{1}, \mathrm{v}_{2}, \ldots \mathrm{v}_{\mathrm{n}}=\mathrm{v}$ in $\mathrm{G}$ is $\ell_{\mathrm{F}}(\mathrm{P})=\sum_{\mathrm{i}=1}^{\mathrm{n}} \frac{1}{\mathrm{~F}_{\mathrm{B}}\left(\mathrm{v}_{\mathrm{i}-1}, \mathrm{v}_{\mathrm{i}}\right)}$, where $\mathrm{v}_{\mathrm{i}} \in \mathrm{V}$,

i.e., $\delta_{\mathrm{F}}(\mathrm{u}, \mathrm{v})=\min \left(\ell_{\mathrm{F}}(\mathrm{P})\right)$.

The distance $\delta(\mathrm{u}, \mathrm{v})$ is defined as $\delta(\mathrm{u}, \mathrm{v})=\left(\delta_{\mathrm{T}}(\mathrm{u}, \mathrm{v}), \delta_{\mathrm{I}}(\mathrm{u}, \mathrm{v}), \delta_{\mathrm{F}}(\mathrm{u}, \mathrm{v})\right)$.

For each $\mathrm{v}_{\mathrm{i}} \in \mathrm{V}$, the $\mathrm{T}$ - eccentricity of $\mathrm{v}_{\mathrm{i}}$ is denoted by $\mathrm{e}_{\mathrm{T}}\left(\mathrm{v}_{\mathrm{i}}\right)$ and is defined as $\mathrm{e}_{\mathrm{T}}\left(\mathrm{v}_{\mathrm{i}}\right)=\max \left\{\delta_{\mathrm{T}}\left(\mathrm{v}_{\mathrm{i}}, \mathrm{v}_{\mathrm{j}}\right) \mid \mathrm{v}_{\mathrm{j}} \in \mathrm{V}, \mathrm{v}_{\mathrm{i}} \neq \mathrm{v}_{\mathrm{j}}\right\}$.

For each $v_{i} \in V$, the $I-$ eccentricity of $v_{i}$ is denoted by $e_{I}\left(v_{i}\right)$ and is defined as $\mathrm{e}_{\mathrm{I}}\left(\mathrm{v}_{\mathrm{i}}\right)=\max \left\{\delta_{\mathrm{I}}\left(\mathrm{v}_{\mathrm{i}}, \mathrm{v}_{\mathrm{j}}\right) \mid \mathrm{v}_{\mathrm{j}} \in \mathrm{V}, \mathrm{v}_{\mathrm{i}} \neq \mathrm{v}_{\mathrm{j}}\right\}$.

For each $v_{i} \in V$, the $F$ - eccentricity of $v_{i}$ is denoted by $e_{F}\left(v_{i}\right)$ and is defined as $\mathrm{e}_{\mathrm{F}}\left(\mathrm{v}_{\mathrm{i}}\right)=\max \left\{\delta_{\mathrm{F}}\left(\mathrm{v}_{\mathrm{i}}, \mathrm{v}_{\mathrm{j}}\right) \mid \mathrm{v}_{\mathrm{j}} \in \mathrm{V}, \mathrm{v}_{\mathrm{i}} \neq \mathrm{v}_{\mathrm{j}}\right\}$.

For each $v_{i} \in V$, the eccentricity of $v_{i}$ is denoted by $e\left(v_{i}\right)$ and is defined as $\mathrm{e}\left(\mathrm{v}_{\mathrm{i}}\right)=\left(\mathrm{e}_{\mathrm{T}}\left(\mathrm{v}_{\mathrm{i}}\right), \mathrm{e}_{\mathrm{I}}\left(\mathrm{v}_{\mathrm{i}}\right), \mathrm{e}_{\mathrm{F}}\left(\mathrm{v}_{\mathrm{i}}\right)\right)$.

The $\mathrm{T}$ - radius of $\mathrm{G}$ is denoted by $\mathrm{r}_{\mathrm{T}}(\mathrm{G})$ and is defined as $\mathrm{r}_{\mathrm{T}}(\mathrm{G})=\min \left\{\mathrm{e}_{\mathrm{T}}\left(\mathrm{v}_{\mathrm{i}}\right) \mid \mathrm{v}_{\mathrm{i}} \in \mathrm{V}\right\}$. The $I$ - radius of $G$ is denoted by $r_{I}(G)$ and is defined as $r_{I}(G)=\min \left\{e_{I}\left(v_{i}\right) \mid v_{i} \in V\right\}$. The $F$ - radius of $G$ is denoted by $r_{F}(G)$ and is defined as $r_{F}(G)=\min \left\{e_{F}\left(v_{i}\right) \mid v_{i} \in V\right\}$. The radius of $G$ is denoted by $r(G)$ and is defined by $r(G)=\left(r_{T}(G), r_{I}(G), r_{F}(G)\right)$.

The $T$ - diameter of $G$ is denoted by $d_{T}(G)$ and is defined as $d_{T}(G)=$ $\max \left\{\mathrm{e}_{\mathrm{T}}\left(\mathrm{v}_{\mathrm{i}}\right) \mid \mathrm{v}_{\mathrm{i}} \in \mathrm{V}\right\}$. The $\mathrm{I}$ - diameter of $\mathrm{G}$ is denoted by $d(G)$ and is defined as $d_{I}(G)=\max \left\{e_{I}\left(v_{i}\right) \mid v_{i} \in V\right\}$. The $F-$ diameter of $G$ is denoted by $d_{F}(G)$ and is defined as $d_{F}(G)=\max \left\{e_{F}\left(v_{i}\right) \mid v_{i} \in V\right\}$. The diameter of $G$ is denoted by $d(G)$ and is defined by $d(G)=\left(d_{T}(G), d_{I}(G), d(G)\right)$.

A connected single valued neutrosophic graph is a self centred graph, if every vertex of $G$ is a central vertex, that is $r_{T}(G)=e_{T}\left(v_{i}\right), r_{I}(G)=e_{I}\left(v_{i}\right)$ and $r_{F}(G)=$ $\mathrm{e}_{\mathrm{F}}\left(\mathrm{v}_{\mathrm{i}}\right)$.

Example 2. An SVN graph with $\mathrm{r}(\mathrm{G})=(5.5,5,1.7), \mathrm{d}(\mathrm{G})=(10,10,3.3)$

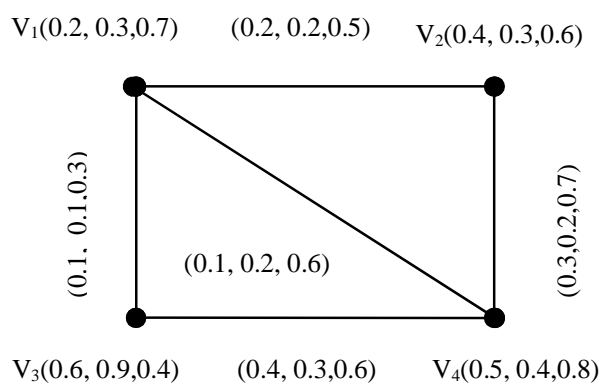

Figure 2:

Definition 2.11. Let $G$ and $G^{\prime}$ be single valued neutrosophic graphs with underlying sets $\mathrm{V}$ and $\mathrm{V}^{\prime}$ respectively. A homomorphism of single valued neutrosophic graphs, $\mathrm{h}: \mathrm{G} \rightarrow$ $\mathrm{G}^{\prime}$ is a map $\mathrm{h}: \mathrm{V} \rightarrow \mathrm{V}^{\prime}$ which satisfies 
On Antipodal Single Valued Neutrosophic Graph

$\mathrm{T}_{\mathrm{A}}(\mathrm{u}) \leq \mathrm{T}_{\mathrm{A}^{\prime}}(\mathrm{h}(\mathrm{u})), \mathrm{I}_{\mathrm{A}}(\mathrm{u}) \leq \mathrm{I}_{\mathrm{A}^{\prime}}(\mathrm{h}(\mathrm{u})), \mathrm{F}_{\mathrm{A}}(\mathrm{u}) \leq \mathrm{F}_{\mathrm{A}^{\prime}}(\mathrm{h}(\mathrm{u}))$ for all $\mathrm{u} \in \mathrm{V}$ $\mathrm{T}_{\mathrm{B}}(\mathrm{u}, \mathrm{v}) \leq \mathrm{T}_{\mathrm{A}^{\prime}}(\mathrm{h}(\mathrm{u}), \mathrm{h}(\mathrm{v})), \mathrm{I}_{\mathrm{B}}(\mathrm{u}, \mathrm{v}) \leq \mathrm{I}_{\mathrm{B}^{\prime}}(\mathrm{h}(\mathrm{u}), \mathrm{h}(\mathrm{v})), \mathrm{F}_{\mathrm{B}}(\mathrm{u}, \mathrm{v}) \leq \mathrm{F}_{\mathrm{B}^{\prime}}(\mathrm{h}(\mathrm{u}), \mathrm{h}(\mathrm{v}))$ for all $u, v \in V$.

Definition 2.12. Let $G$ and $G^{\prime}$ be single valued neutrosophic graphs with underlying sets $\mathrm{V}$ and $\mathrm{V}^{\prime}$ respectively. An isomorphism of single valued neutrosophic graphs, $\mathrm{h}: \mathrm{G} \rightarrow \mathrm{G}^{\prime}$ is a bijective map $\mathrm{h}: \mathrm{V} \rightarrow \mathrm{V}^{\prime}$ which satisfies

$\mathrm{T}_{\mathrm{A}}(\mathrm{u})=\mathrm{T}_{\mathrm{A}^{\prime}}(\mathrm{h}(\mathrm{u})), \mathrm{I}_{\mathrm{A}}(\mathrm{u})=\mathrm{I}_{\mathrm{A}^{\prime}}(\mathrm{h}(\mathrm{u})), \mathrm{F}_{\mathrm{A}}(\mathrm{u})=\mathrm{F}_{\mathrm{A}^{\prime}}(\mathrm{h}(\mathrm{u}))$ for all $\mathrm{u} \in \mathrm{V}$

$\mathrm{T}_{\mathrm{B}}(\mathrm{u}, \mathrm{v})=\mathrm{T}_{\mathrm{B}^{\prime}}(\mathrm{h}(\mathrm{u}), \mathrm{h}(\mathrm{v})), \mathrm{I}_{\mathrm{B}}(\mathrm{u}, \mathrm{v})=\mathrm{I}_{\mathrm{B}^{\prime}}(\mathrm{h}(\mathrm{u}), \mathrm{h}(\mathrm{v})), \mathrm{F}_{\mathrm{B}}(\mathrm{u}, \mathrm{v})=\mathrm{F}_{\mathrm{B}^{\prime}}(\mathrm{h}(\mathrm{u}), \mathrm{h}(\mathrm{v}))$ for all $\mathrm{u}, \mathrm{v} \in \mathrm{V}$.

Then $G$ is said to be isomorphic to $G^{\prime}$.

Definition 2.13. A weak isomorphism of single valued neutrosophic graphs, $h: G \rightarrow G^{\prime}$ is a map $\mathrm{h}: \mathrm{V} \rightarrow \mathrm{V}^{\prime}$ which is a bijective homomorphism that satisfies

$$
\mathrm{T}_{\mathrm{A}}(\mathrm{u})=\mathrm{T}_{\mathrm{A}^{\prime}}(\mathrm{h}(\mathrm{u})), \mathrm{I}_{\mathrm{A}}(\mathrm{u})=\mathrm{I}_{\mathrm{A}^{\prime}}(\mathrm{h}(\mathrm{u})), \mathrm{F}_{\mathrm{A}}(\mathrm{u})=\mathrm{F}_{\mathrm{A}^{\prime}}(\mathrm{h}(\mathrm{u})) \text { for all } \mathrm{u} \in \mathrm{V}
$$

Definition 2.14. A co-weak isomorphism of single valued neutrosophic graphs, $h: G \rightarrow$ $\mathrm{G}^{\prime}$ is a map $\mathrm{h}: \mathrm{V} \rightarrow \mathrm{V}^{\prime}$ which is a bijective homomorphism that satisfies $T_{B}(\mathrm{u}, \mathrm{v})=$ $T_{B^{\prime}}(h(u), h(v)), I_{B}(u, v)=I_{B^{\prime}}(h(u), h(v)), F_{B}(u, v)=F_{B^{\prime}}(h(u), h(v))$ for all $u, v \in V$.

\section{Main results}

Definition 3.1. Let $\mathrm{G}=(\mathrm{A}, \mathrm{B})$ be a single valued neutrosophic graph. An antipodal single valued neutrosophic graph $\mathrm{A}(\mathrm{G})=(\mathrm{P}, \mathrm{Q})$ is a single valued neutrosophic graph of $\mathrm{G}=$ $(\mathrm{A}, \mathrm{B})$ in which:

(a) An single valued neutrosophic vertex set of $G$ is taken as single valued neutrosophic vertex set of $A(G)$, that is,

$$
\begin{aligned}
& T_{P}(x)=T_{A}(x), \\
& I_{P}(x)=I_{A}(x), \\
& F_{P}(x)=F_{A}(x) \text { for all } x \in V,
\end{aligned}
$$

(b) If $\delta(x, y)=d(G)$, then $x$ and $y$ are made as neighbours in $A(G)$ such that

$$
\begin{array}{lc}
\mathrm{T}_{Q}(\mathrm{x}, \mathrm{y})=\mathrm{T}_{\mathrm{B}}(\mathrm{x}, \mathrm{y}) & \text { if } \mathrm{x} \text { and } \mathrm{y} \text { are neighbors in } \mathrm{G} \\
\mathrm{T}_{\mathrm{Q}}(\mathrm{x}, \mathrm{y})=\min \left(\mathrm{T}_{\mathrm{A}}(\mathrm{x}), \mathrm{T}_{\mathrm{A}}(\mathrm{y})\right) & \text { if } \mathrm{x} \text { and } \mathrm{y} \text { are not neighbors in } \mathrm{G} \\
\mathrm{I}_{\mathrm{Q}}(\mathrm{x}, \mathrm{y})=\mathrm{I}_{\mathrm{B}}(\mathrm{x}, \mathrm{y}) & \text { if } \mathrm{x} \text { and } \mathrm{y} \text { are neighbors in } \mathrm{G} \\
\mathrm{I}_{\mathrm{Q}}(\mathrm{x}, \mathrm{y})=\min \left(\mathrm{I}_{\mathrm{A}}(\mathrm{x}), \mathrm{I}_{\mathrm{A}}(\mathrm{y})\right) & \text { if } \mathrm{x} \text { and } \mathrm{y} \text { are not neighbors in } \mathrm{G} \\
\mathrm{F}_{\mathrm{Q}}(\mathrm{x}, \mathrm{y})=\mathrm{F}_{\mathrm{B}}(\mathrm{x}, \mathrm{y}) & \text { if } \mathrm{x} \text { and } \mathrm{y} \text { are neighbors in } \mathrm{G} \\
\mathrm{F}_{\mathrm{Q}}(\mathrm{x}, \mathrm{y})=\max \left(\mathrm{F}_{\mathrm{A}}(\mathrm{x}), \mathrm{F}_{\mathrm{A}}(\mathrm{y})\right) & \text { if } \mathrm{x} \text { and } \mathrm{y} \text { are not neighbors in } \mathrm{G}
\end{array}
$$

That is, two vertices in $\mathrm{A}(\mathrm{G})$ are made as neighborhood if the T,I,F -distance between them is diameter of $\mathrm{G}$. 
Example 3.2.
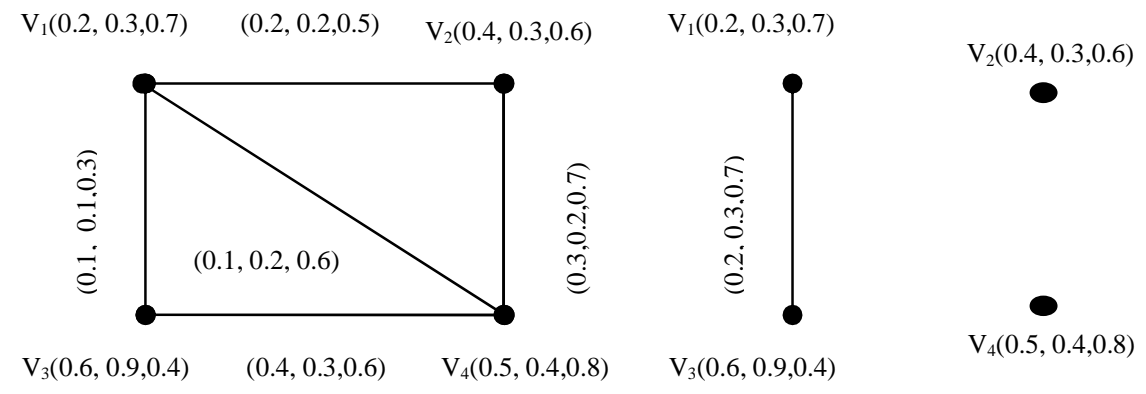

(a) SVN graph

Figure 3:

(b) Antipodal SVN graph

Theorem 3.3. Let $G=(A, B)$ be a complete single valued neutrosophic graph where $\left(T_{A}\right.$, $\left.I_{A}, F_{A}\right)$ is constant function then $G$ is isomorphic to $A(G)=(P, Q)$.

Proof: Given that $G=(A, B)$ be a complete single valued neutrosophic graph with $\left(T_{A}\right.$, $\left.\mathrm{I}_{\mathrm{A}}, \mathrm{F}_{\mathrm{A}}\right)=\left(\mathrm{k}_{1}, \mathrm{k}_{2}, \mathrm{k}_{3}\right)$, where $\mathrm{k}_{1}, \mathrm{k}_{2}$, and $\mathrm{k}_{3}$ are constants, which implies that $\delta\left(\mathrm{v}_{\mathrm{i}}, \mathrm{v}_{\mathrm{j}}\right)=\left(\mathrm{l}_{1}\right.$, $\left.\mathrm{l}_{2}, \mathrm{l}_{3}\right) \forall \mathrm{v}_{\mathrm{i}}, \mathrm{v}_{\mathrm{j}} \in \mathrm{V}$. Therefore, eccentricity $\mathrm{e}\left(\mathrm{v}_{\mathrm{i}}\right)=\left(\mathrm{l}_{1}, \mathrm{l}_{2}, \mathrm{l}_{3}\right), \forall \mathrm{vi} \in \mathrm{V}$, which implies that $\mathrm{d}(\mathrm{G})=\left(\mathrm{l}_{1}, \mathrm{l}_{2}, \mathrm{l}_{3}\right)$. Hence $\delta\left(\mathrm{v}_{\mathrm{i}}, \mathrm{v}_{\mathrm{j}}\right)=\left(1_{1}, 1_{2}, \mathrm{l}_{3}\right)=\mathrm{d}(\mathrm{G}), \forall \mathrm{v}_{\mathrm{i}}, \mathrm{v}_{\mathrm{j}} \in \mathrm{V}$. Hence those vertices which are neighbous in $G$ are also neighbors in $A(G)$ such that

(a) A single valued neutrosophic vertex set of $G$ is taken as single valued neutrosophic vertex set of $A(G)$, that is,

$$
\begin{aligned}
& T_{P}\left(v_{i}\right)=T_{A}\left(v_{i}\right), \\
& I_{P}\left(v_{i}\right)=I_{A}\left(v_{i}\right), \\
& F_{P}\left(v_{i}\right)=F_{A}\left(v_{i}\right)
\end{aligned}
$$

for all $v_{i} \in V$,

(b) $\quad \mathrm{T}_{\mathrm{Q}}\left(\mathrm{v}_{\mathrm{i}} \mathrm{v}_{\mathrm{j}}\right)=\mathrm{T}_{\mathrm{B}}\left(\mathrm{v}_{\mathrm{i}} \mathrm{v}_{\mathrm{j}}\right)$

since $v_{i}$ and $v_{j}$ are neighbors in $G$

$\mathrm{I}_{\mathrm{Q}}\left(\mathrm{v}_{\mathrm{i}} \mathrm{v}_{\mathrm{j}}\right)=\mathrm{I}_{\mathrm{B}}\left(\mathrm{v}_{\mathrm{i}} \mathrm{v}_{\mathrm{j}}\right)$

since $v_{i}$ and $v_{j}$ are neighbors in $G$

$\mathrm{F}_{\mathrm{Q}}\left(\mathrm{v}_{\mathrm{i}} \mathrm{v}_{\mathrm{j}}\right)=\mathrm{F}_{\mathrm{B}}\left(\mathrm{v}_{\mathrm{i}} \mathrm{v}_{\mathrm{j}}\right)$

since $v_{i}$ and $v_{j}$ are neighbors in $G$

Taking the mapping from $\mathrm{G} \rightarrow \mathrm{A}(\mathrm{G})$ as $\mathrm{i}: \mathrm{A} \rightarrow \mathrm{P}, \mathrm{G} \cong \mathrm{A}(\mathrm{G})$.

Theorem 3.4. If $G_{1}$ and $G_{2}$ are isomorphic to each other, then $A\left(G_{1}\right)$ and $A\left(G_{2}\right)$ are also isomorphic.

Proof: $A s G_{1}$ and $G_{2}$ are isomorphic, the isomorphism $h$, between them pre-serves the edge weights, so the T,I,F - length and T,I,F- distance will also be pre-served. Hence, if the vertex $v_{i}$ has the maximum $T$ - eccentricity, maximum $\mathrm{I}$ - eccentricity and minimum $\mathrm{F}$ - eccentricity, in $\mathrm{G}_{1}$, then $\mathrm{h}\left(\mathrm{v}_{\mathrm{i}}\right)$ has the maximum $\mathrm{T}$ - eccentricity, maximum I eccentricity and minimum $F$ - eccentricity, in $G_{2}$. So, $G_{1}$ and $G_{2}$ will have the same diameter. If the T,I,F - distance between $v_{i}$ and $v_{j}$ is $\left(k_{1}, k_{2}, k_{3}\right)$ in $G_{1}$, then $h\left(v_{i}\right)$ and $h\left(v_{j}\right)$ will also have their T,I,F - distance as $\left(\mathrm{k}_{1}, \mathrm{k}_{2}, \mathrm{k}_{3}\right)$ in $\mathrm{G}_{2}$. The same mapping $\mathrm{h}$ itself is a bijection between $A\left(G_{1}\right)$ and $A\left(G_{2}\right)$ satisfying the isomorphism condition.

(i) $\mathrm{T}_{\mathrm{P}_{1}}\left(\mathrm{v}_{\mathrm{i}}\right)=\mathrm{T}_{\mathrm{A}_{1}}\left(\mathrm{v}_{\mathrm{i}}\right)=\mathrm{T}_{\mathrm{A}_{2}}\left(\mathrm{~h}\left(\mathrm{v}_{\mathrm{i}}\right)\right)=\mathrm{T}_{\mathrm{P}_{2}}\left(\mathrm{~h}\left(\mathrm{v}_{\mathrm{i}}\right)\right) \forall \mathrm{v}_{\mathrm{i}} \in \mathrm{G}_{1}$

(ii) $\mathrm{I}_{\mathrm{P}_{1}}\left(\mathrm{v}_{\mathrm{i}}\right)=\mathrm{I}_{\mathrm{A}_{1}}\left(\mathrm{v}_{\mathrm{i}}\right)=\mathrm{I}_{\mathrm{A}_{2}}\left(\mathrm{~h}\left(\mathrm{v}_{\mathrm{i}}\right)\right)=\mathrm{I}_{\mathrm{P}_{2}}\left(\mathrm{~h}\left(\mathrm{v}_{\mathrm{i}}\right)\right) \forall \mathrm{v}_{\mathrm{i}} \in \mathrm{G}_{1}$

(iii) $\mathrm{F}_{\mathrm{P}_{1}}\left(\mathrm{v}_{\mathrm{i}}\right)=\mathrm{F}_{\mathrm{A}_{1}}\left(\mathrm{v}_{\mathrm{i}}\right)=\mathrm{F}_{\mathrm{A}_{2}}\left(\mathrm{~h}\left(\mathrm{v}_{\mathrm{i}}\right)\right)=\mathrm{F}_{\mathrm{P}_{2}}\left(\mathrm{~h}\left(\mathrm{v}_{\mathrm{i}}\right)\right) \forall \mathrm{v}_{\mathrm{i}} \in \mathrm{G}_{1}$ 
On Antipodal Single Valued Neutrosophic Graph

(iv) $\mathrm{T}_{\mathrm{Q}_{1}}\left(\mathrm{v}_{\mathrm{i}}, \mathrm{v}_{\mathrm{j}}\right)=\mathrm{T}_{\mathrm{B}_{1}}\left(\mathrm{v}_{\mathrm{i}}, \mathrm{v}_{\mathrm{j}}\right)$

if $v_{i}$ and $v_{j}$ are neighbors in $G_{1}$

$\mathrm{T}_{\mathrm{Q}_{1}}\left(\mathrm{v}_{\mathrm{i}}, \mathrm{v}_{\mathrm{j}}\right)=\min \left(\mathrm{T}_{\mathrm{P}_{1}}\left(\mathrm{v}_{\mathrm{i}}\right), \mathrm{T}_{\mathrm{P}_{1}}\left(\mathrm{v}_{\mathrm{j}}\right)\right) \quad$ if $\mathrm{v}_{\mathrm{i}}$ and $\mathrm{v}_{\mathrm{j}}$ are not neighbors in $\mathrm{G}_{1}$

(v) $\mathrm{I}_{\mathrm{Q}_{1}}\left(\mathrm{v}_{\mathrm{i}}, \mathrm{v}_{\mathrm{j}}\right)=\mathrm{I}_{\mathrm{B}_{1}}\left(\mathrm{v}_{\mathrm{i}}, \mathrm{v}_{\mathrm{j}}\right)$ if $v_{i}$ and $v_{j}$ are neighbors in $G_{1}$

$\mathrm{I}_{\mathrm{Q}_{1}}\left(\mathrm{v}_{\mathrm{i}}, \mathrm{v}_{\mathrm{j}}\right)=\min \left(\mathrm{I}_{\mathrm{P}_{1}}\left(\mathrm{v}_{\mathrm{i}}\right), \mathrm{I}_{\mathrm{P}_{1}}\left(\mathrm{v}_{\mathrm{j}}\right)\right) \quad$ if $\mathrm{v}_{\mathrm{i}}$ and $\mathrm{v}_{\mathrm{j}}$ are not neighbors in $\mathrm{G}_{1}$

(vi) $\mathrm{F}_{\mathrm{Q}_{1}}\left(\mathrm{v}_{\mathrm{i}}, \mathrm{v}_{\mathrm{j}}\right)=\mathrm{F}_{\mathrm{B}_{1}}\left(\mathrm{v}_{\mathrm{i}}, \mathrm{v}_{\mathrm{j}}\right)$ if $v_{i}$ and $v_{j}$ are neighbors in $G_{1}$

$\mathrm{F}_{\mathrm{Q}_{1}}\left(\mathrm{v}_{\mathrm{i}}, \mathrm{v}_{\mathrm{j}}\right)=\max \left(\mathrm{F}_{\mathrm{P}_{1}}\left(\mathrm{v}_{\mathrm{i}}\right), \mathrm{F}_{\mathrm{P}_{1}}\left(\mathrm{v}_{\mathrm{j}}\right)\right) \quad$ if $\mathrm{v}_{\mathrm{i}}$ and $\mathrm{v}_{\mathrm{j}}$ are not neighbors in $\mathrm{G}_{1}$

As $h: G_{1} \rightarrow G_{2}$ is an isomorphism,

$$
\begin{aligned}
& T_{Q_{1}}\left(v_{i}, v_{j}\right) \\
= & T_{B_{2}}\left(h(v)_{i}, h\left(v_{j}\right)\right) \\
= & \min \left(T_{B_{2}}\left(h\left(v_{i}\right)\right), T_{B_{2}}\left(h\left(v_{j}\right)\right)\right) \\
= & I_{B_{2}}\left(h(v)_{i}, h\left(v_{j}\right)\right) \\
= & \min \left(I_{B_{2}}\left(h\left(v_{i}\right)\right), I_{B_{2}}\left(h\left(v_{j}\right)\right)\right) \\
& F_{Q_{1}}\left(v_{i}, v_{j}\right)=F_{B_{2}}\left(h(v)_{i}, h\left(v_{j}\right)\right)
\end{aligned}
$$

if $v_{i}$ and $v_{j}$ are neighbors in $G_{1} T_{Q_{1}}\left(v_{i}, v_{j}\right)$

if $v_{i}$ and $v_{j}$ are not neighbors in $G_{1} I_{Q_{1}}\left(v_{i}, v_{j}\right)$

if $v_{i}$ and $v_{j}$ are neighbors in $G_{1} I_{Q_{1}}\left(v_{i}, v_{j}\right)$

if $v_{i}$ and $v_{j}$ are not neighbors in $G_{1}$

if $v_{i}$ and $v_{j}$ are neighbors in $G_{1}$

Hence $\mathrm{T}_{\mathrm{Q}_{1}}\left(\mathrm{v}_{\mathrm{i}}, \mathrm{v}_{\mathrm{j}}\right)=\mathrm{T}_{\mathrm{Q}_{2}}\left(\mathrm{~h}(\mathrm{v})_{\mathrm{i}}, \mathrm{h}\left(\mathrm{v}_{\mathrm{j}}\right)\right), \mathrm{I}_{\mathrm{Q}_{1}}\left(\mathrm{v}_{\mathrm{i}}, \mathrm{v}_{\mathrm{j}}\right)=\mathrm{I}_{\mathrm{Q}_{2}}\left(\mathrm{~h}(\mathrm{v})_{\mathrm{i}}, \mathrm{h}\left(\mathrm{v}_{\mathrm{j}}\right)\right)$ and

$\mathrm{F}_{\mathrm{Q}_{1}}\left(\mathrm{v}_{\mathrm{i}}, \mathrm{v}_{\mathrm{j}}\right)=\max \left(\mathrm{F}_{\mathrm{B}_{2}}\left(\mathrm{~h}\left(\mathrm{v}_{\mathrm{i}}\right)\right), \mathrm{F}_{\mathrm{B}_{2}}\left(\mathrm{~h}\left(\mathrm{v}_{\mathrm{j}}\right)\right)\right.$ if $\mathrm{v}_{\mathrm{i}}$ and $\mathrm{v}_{\mathrm{j}}$ are not neighbors in $\mathrm{G}_{1}$

$F_{Q_{1}}\left(v_{i}, v_{j}\right)=F_{Q_{2}}\left(h(v)_{i}, h\left(v_{j}\right)\right)$. So, the same $h$ is an isomorphism between $A\left(G_{1}\right)$ and $A\left(G_{2}\right)$.

Theorem 3.5. If $\mathrm{G}_{1}=\left(\mathrm{A}_{1}, \mathrm{~B}_{1}\right)$ and $\mathrm{G}_{2}=\left(\mathrm{A}_{2}, \mathrm{~B}_{2}\right)$ are complete single valued neutrosophic graph such that $G_{1}$ is co-weak isomorphic to $G_{2}$ then $A\left(G_{1}\right)$ is co-weak isomorphic to $A\left(G_{2}\right)$.

Proof: As $\mathrm{G}_{1}$ is co-weak isomorphic to $\mathrm{G}_{2}$, there exists a bijection $\mathrm{h}: \mathrm{G}_{1} \rightarrow \mathrm{G}_{2}$ satisfying, $\mathrm{T}_{\mathrm{A}_{1}}\left(\mathrm{v}_{\mathrm{i}}\right) \leq \mathrm{T}_{\mathrm{A}_{2}}\left(\mathrm{~h}\left(\mathrm{v}_{\mathrm{i}}\right)\right), \mathrm{T}_{\mathrm{B}_{1}}\left(\mathrm{v}_{\mathrm{i}}, \mathrm{v}_{\mathrm{j}}\right)=\mathrm{T}_{\mathrm{B}_{2}}\left(\mathrm{~h}\left(\mathrm{v}_{\mathrm{i}}\right), \mathrm{h}\left(\mathrm{v}_{\mathrm{j}}\right)\right), \forall \mathrm{v}_{\mathrm{i}}, \mathrm{v}_{\mathrm{j}} \in \mathrm{v}_{1}$.

If $G_{1}$ has $n$ vertices, arrange the vertices of $G_{1}$ in such a way that $T_{A_{1}}\left(v_{1}\right) \leq T_{A_{1}}\left(v_{2}\right) \leq$ $\mathrm{T}_{\mathrm{A}_{1}}\left(\mathrm{v}_{3}\right) \leq \cdots \leq \mathrm{T}_{\mathrm{A}_{1}}\left(\mathrm{v}_{\mathrm{n}}\right)$. As $\mathrm{G}_{1}$ and $\mathrm{G}_{2}$ are complete, co-weak isomorphic single valued neutrosophic graph $\mathrm{T}_{\mathrm{B}_{1}}\left(\mathrm{v}_{\mathrm{i}}, \mathrm{v}_{\mathrm{j}}\right)=\mathrm{T}_{\mathrm{B}_{2}}\left(\mathrm{~h}\left(\mathrm{v}_{\mathrm{i}}\right), \mathrm{h}\left(\mathrm{v}_{\mathrm{j}}\right)\right), \forall \mathrm{v}_{\mathrm{i}}, \mathrm{v}_{\mathrm{j}} \in \mathrm{v}_{1}$. By Theorem 3.4 and the definition of antipodal single valued neutrosophic graph, we have $A\left(G_{i}\right)$ contains all the vertices of $\mathrm{G}$, where $\mathrm{i}=1,2$. That is, $\mathrm{T}_{\mathrm{P}_{1}}(\mathrm{x})=\mathrm{T}_{\mathrm{A}_{1}}(\mathrm{x}), \mathrm{I}_{\mathrm{P}_{1}}(\mathrm{x})=\mathrm{I}_{\mathrm{A}_{1}}(\mathrm{x})$ and $\mathrm{F}_{\mathrm{P}_{1}}(\mathrm{x})=$ $\mathrm{F}_{\mathrm{A}_{1}}(\mathrm{x})$ for all $\mathrm{x} \in \mathrm{V}$ and $\mathrm{T}_{\mathrm{Q}_{1}}\left(\mathrm{v}_{\mathrm{i}}, \mathrm{v}_{\mathrm{j}}\right)=\mathrm{T}_{\mathrm{Q}_{2}}\left(\mathrm{~h}\left(\mathrm{v}_{\mathrm{i}}\right), \mathrm{h}\left(\mathrm{v}_{\mathrm{j}}\right)\right), \forall \mathrm{v}_{\mathrm{i}}, \mathrm{v}_{\mathrm{j}} \in \mathrm{V}_{1}$. So, the same bijection $h$ is a co-weak isomorphism between $A\left(G_{1}\right)$ and $A\left(G_{2}\right)$.

\section{RERFERNCES}

1. M.Akram, Sheng-Gang Li amd K.P.Shum, Antipodal bipolar fuzzy graphs, Italian Journal of Pure and Applied Mathematics, 31 (2013) (97 -110).

2. M.Akram, Bipolar fuzzy graphs, Information Sciences, 181 (2011) 5548-5564.

3. R.Aravamudhan and B.Rajendran, On antipodal graphs, Discrete Math., 49 (1984) 193-195. 


\section{J. Malarvizhi and G.Divya}

4. S.Broumi, M.A.Talea, A. Bakali and F. Smarandache, Single-valued neutrosophic graphs, Journal of New Theory, 10 (2016) $86-101$.

5. A.N.Gani and J.Malarvizhi, On antipodal fuzzy graph, Applied Mathematical Sciences, 4 (43) (2010) 2145-2155.

6. J.N.Mordeson and P.S.Nair, Fuzzy graphs and fuzzy hypergraphs, Physica Verlag, Heidelberg 1998; Second Edition 2001.

7. M.Akram and G.Shahzadi, Operations on single-valued neutrosophic graphs, Journal of Uncertain Systems, 11(1) (2017) 1-26.

8. F.Smarandache, A unifying field in logics neutrosophy: Neutrosophic probability, set and logic, Re-hoboth: American Research Press, 1998. 